\title{
European Memory in Populism
}

Representations of Self and Other

Edited by Chiara De Cesari and Ayhan Kaya

First Published 2020

ISBN: 978- I- | 38-3 |8| I-3 (hbk)

ISBN: 978-0-429-4548I-3 (ebk)

Chapter 4

'A great bliss to keep the sensation of conquest alive!'

The emotional politics of the Panorama I 453 Museum in Istanbul

Gönül Bozoğlu

(CC BY-NC-ND 4.0) 


\section{'A great bliss to keep the sensation of conquest alive!' The emotional politics of the Panorama I 453 Museum in Istanbul}

\section{Gönül Bozoğlu}

\section{Introduction}

The quotation in the title of this chapter is from a comment endorsing the Panorama 1453 Museum, made upon its opening in 2009 by Özleyis Topbaş, wife of the then-mayor of Istanbul, Kadir Topbaş. ${ }^{1}$ Until recently, the comment was used to market the museum on its website, alongside others by prominent members or supporters of the conservative-Islamist administration of the Adalet ve Kalkınma Partisi (Justice and Development Party, henceforth JDP). The JDP has focused significant effort on fostering public memory of the capture of the Byzantine city of Constantinople on 29 May 1453. Festivities, re-enactments, public imagery, and the spectacular Panorama 1453 Museum tell a glorious story of the Ottoman victory and the magnanimous treatment of the defeated Byzantines. In these narratives, public audiences are invited to identify with the Ottomans, and to celebrate a 'Turkish' claim to presence reliant on the Hadith in which the conquest is prophesied. Meanwhile, references to the Ottoman past in JDP discourse are frequent.

One aim of this chapter is to foreground the interplay of official heritage and political discourse. Here I will argue that in the populist rhetoric and cultural interventions of the JDP the historic, expansionist encroachment on others is glorified, and Islam is placed at the heart of the story of Turkish identity and homeland, contrary to the secular, Westernized identity of the early Republic. A second aim of this chapter is to analyze the responses to this governmental and authorized heritage by visitors whom I surveyed though short interviews. Here, the politics and affects of people's encounters with the Conquest in the museum need to be related, on the one hand, to the emotional appeals of the JDP's nostalgic populism - which concerns the need to recover a glorious past that has been stolen by political foes - and, on the other, to visitors' resentment towards those very foes: the disempowered secular elites. These, rather than the Byzantines, are the real enemy for the museum's audiences. Finally, this chapter explores the social and political role of the museum in providing a space for the expression of animosity. This consolidates social division and polarization in the interests of the status quo, while also representing the 
overlaps between political, emotional, and memory cultures and communities. In exploring this, I seek to work in alignment with recent thinking in heritage studies that develops understandings of the interrelations between historical memory culture, politics, and emotion, as exemplified by Laurajane Smith and Gary Campbell:

If we accept that heritage is political, that it is a political resource used in conflicts over the understanding of the past and its relevance for the present, then understanding how the interplay of emotions, imagination and the process of remembering and commemoration are informed by people's culturally and socially diverse affective responses must become a growing area of focus for the field.

In this chapter it is Ottoman heritage that is the 'political resource' described above. This is because it offers a compendium of values that can be mined by party-political actors to present ideals of national identity and citizenship. At the same time, my research found that such official attempts to 'bring back' the Ottoman past as national history - foregrounding 1453 and not 1923 (the foundation of the Turkish Republic) - was a potent means of tapping into conservative-Islamist audiences' sense of long suffering and suppression under the stridently secularist regimes prior to JDP ascendancy. This means that remembering the Conquest is bound up with a sense of loss, anger, and antagonistic reference to one's enemies at home, alongside a sense that it is finally possible to return to a true identity after decades of injustice.

In the 1994 local elections, an Islamist party - the Welfare Party (Refah Partisi) won a decisive victory and conservative-Islamist mayors were installed in many municipalities, including Istanbul; then, in the 1995 general elections, the party won the majority of the vote. With the rise of the Welfare Party, the prominence of Islam in the public domain increased (Göle, 1997; Navaro-Yashin, 2002) and Ottoman history became yet more visible (White, 2014: 8-9).

The change also occurred in celebration and commemorations of national historical moments. The key events identified by Ottoman historiography were not celebrated during the early Republican era (Çınar, 2001: 365). Rather, during that time new national days were 'invented' in the sense articulated by Hobsbawm and Ranger ([1983]1992) to commemorate Atatürk and the reforms of the early Republic. These include 29 October (the foundation of Turkey in 1923), 23 April (the First Assembly was established in Ankara in 1922; Atatürk devoted this date to children), and 19 May (the date that Atatürk started the War of Liberation). Alongside this is a prominent visual culture relating to Atatürk - who, we should recall, died in 1938 - including literally thousands of photographic and sculptural images of him in public space, not to mention the proliferation of his image in people's houses, or his signature, replicated in bumper stickers and tattoos. 
Nevertheless, in recent years the JDP has moved away from big public celebrations associated with the Republic, to focus instead on Islamic and Ottoman ones. Instead of the celebration of the foundation of the Turkish Republic in 1923, historical events like the Conquest of Constantinople in 1453 have become more central in the public and official sphere, through celebrations and festivities (Çıar, 2001). The Conquest was not absent from state historiography or public commemoration before the changes described above (it was celebrated in 1953, for example), but was of second-order significance compared to the public memory culture relating to Atatürk. In 1994 Erdoğan became mayor of Istanbul, and since then celebrations of the Ottoman past have taken place and gained more stridently Islamist character (Zurcher, 2016). This has involved what I have elsewhere called 'memory wars' (Bozoğlu, 2020), in which memory actors, who are also political actors, more or less associated with party positions, have sought to destabilize or erase memory cultures that they see as inimical to their own. The memory cultures of Atatürk exist today in a tense interrelationship with those of Neo-Ottomanism. But in many ways they also influence and depend on one another, for the stories of heroism and victory are comparable and each relies on its righteous and intransigent opposition to the other. This makes it particularly important for the current administration to invest in the grandeur of 1453. In the anniversary celebrations, re-enactments of the battle symbolically 'perform the conquest again' (Çınar, 2001; Büyüksaraç, 2004; Hürriyet Daily News, 2016). There is also often a re-enactor who plays the role of Sultan Mehmet on his white horse, 're-entering' the city. The meanings of these re-enactment practices can be seen to connect to official practice in museums, and also to political discourse, media representations, and global power plays: as part of the 2017 celebrations, 1,453 lorries were assembled as a world record attempt in a vehicular parade to mark construction of the new Istanbul airport - a past-present relay between the might and achievement of the Ottomans and contemporary Turkey as global powerhouse.

One of the dimensions of so-called neo-Ottomanism is the use of a selective account of the Ottoman past to power identity constructions among the citizenry in the present (Girard, 2015: 3). The JDP's project to rewrite national history with an emphasis on the Ottoman past has been subject to significant and extensive attention and critique. ${ }^{2}$ In one authorized heritage discourse (Smith, 2006), the Ottoman past is presented as a source of pride, and a compendium of virtues and values for people to emulate: indomitable strength, valour, self-sacrifice, and piety. As part of a public discourse of ancestry and descendence, promoted by JDP actors, some people make elective, highly emotional connections between themselves and 'the Ottomans', constructing historical continuities that position them as the inheritors of a legacy of greatness that should be preserved and restored. This discourse, together with immersive spectacles in which people can imagine themselves as Ottomans within the historic scene of the Conquest, are what Geoffrey Cubitt (2007) 
terms 'cultural devices'. These enable people to incorporate a remote past into autobiographical memory, and to bridge the dissonance between past and present: as Topbaş says, to 'keep the sensation of the Conquest alive'. This also occurs in forms of temporal bridging across public and private space: it is possible to buy neo-Ottoman houses; Ottoman clothes are fashionable for events such as circumcision celebrations; JDP politicians break ground for new grand projects on 29 May (the day of the Conquest); Ottoman military music is played in public spaces during Ramadan; and Erdoğan often surrounds himself with men dressed up as Janissary Guards during official appearances. All of these, and many other examples that there is no space to cite, normalize a practice of shuttling between past and present that forecloses any sense of cultural difference between the two.

The discourse of Ottoman revival is articulated across an array of forms of representation, not all of which are in the idiom of 'heritage' in the sense of designated sites, museums, protected traditions, and so on. Indeed, for the Ottoman past to seem really present, it is important that it is not restricted to containers of the past such as museums, but rather spills out into everyday practices and cultural forms. Some of this overspill is manifest in banal discursive connections made in political speeches, or the official naming of new features of the urban landscape. Then, as with the comment from Topbas and the other dignitaries who endorsed the Panorama 1453 Museum, there are instances in which the apparent divide between heritage politics and party politics is bridged: when politicians open museums, or use spectacular, state-funded historical re-enactments as opportunities for giving speeches. Before discussing these relations, I will introduce the museum and its visitors, setting them into the broader context of neo-Ottoman memory culture.

\section{Panorama I 453 Museum}

The Panorama 1453 Museum (P1453) is sited in the Topkap1 area of Istanbul, adjacent to the Land Walls of Istanbul. It was opened in 2006 by (then) Prime Minister Recep Tayyip Erdoğan. By some (but not all) reports, it was Erdogan himself who introduced the idea of a panorama after having visited panoramic museums in Europe during his tenure as mayor of Istanbul (19941998) (Bozoğlu 2020). One of Erdoğan's successors as mayor of Istanbul, Kadir Topbaş (in office 2004-2017), was another key figure in the museum's development, intervening directly in structuring the museum and subsequently using it as a showcase to impress dignitaries and sympathetic journalists (Bozoğlu 2020). While it is clearly not unusual for museums to be opened and used by politicians, in the case of P1453 there was and is an explicit link between the museum and the JDP, and an open correspondence between the party-political uses of the Ottoman past and the stated aims of the museum. In the last lines of the web material, the cultural wing of the Metropolitan Municipality states that it is 'freezing this historical moment and giving it as a gift to the future from 
the 1453 Panorama Museum, which is in a place whose soul enlightens our present as well as our future'. It continues, 'We hope that you will always keep enthusiasm for the conquest alive and that it will inspire future conquerors'.

In governmental terms then, the museum's project of influencing (or indeed 'inspiring') its visitors is not banal, subtle, or subtextual: as we have seen, the political link with the JDP is celebrated. Although expressly partisan, the very use of the museum form - although P1453 has no collection in the conventional museal sense - constitutes an appeal to accuracy and truth-telling about the Conquest. Verbal interpretation makes frequent reference to academic historians consulted during the museum's development, and to the producers' rigorous use of source materials. If this co-presence of an accuracy claim and proudly partisan politics seems paradoxical, it need not be, so long as one accepts that the JDP itself 'speaks truth'. In this sense the party avails itself of the museum as a technology of authority, appropriating its associations as the archetypal institution of objectivity and rigour.

A brief account of the museum's development and its mission and orientation was, until recently, given on the website. ${ }^{3}$ It starts with the description of Topkapı Cultural Park, where the museum is situated:

Topkap1 Cultural Park, a place where an era was closed and a new era was opened, where the epic of the Conquest was written, where Mehmed the second was named as 'Conqueror', a place where Byzantium, Istanbul and hearts were conquered. The Culture Park is the place [adres] of the Ottoman family who flourished in the shadow of the mountains covering the horizon in Söğüt, who opened the breach in the walls of the City and turned into a mighty oak which sprouted many branches.

The oak tree relates to the Dream of Osman I, recounted in the thirteenthcentury Turkish-Anatolian epic poem of the same name, in which Osman's vision of a tree prefigures the Ottomans, as a metaphor of the future growth and spread of Islam. The park itself is home to a number of pavilions, each of which showcases the traditional 'Culture of the Turkic World Neigbourhood' (Türk Dünyası Kültür Mahallesi). This Pan-Turkism goes beyond the Ottoman Empire, for it includes states that were not under Ottoman control. Although it cannot strictly be called a neo-Ottomanist gesture, there are important points of contact, for they both involve reference to Turkey's historic influence in the wider world. In this way the park frames the museum, bringing together different dimensions of neo-Ottomanism as a recovery both of local cultural identity and of global power. This was made yet more explicit in Erdoğan's speech at the museum's opening ceremony:

Istanbul is the heritage of the great world empire; as much as it represents Bursa, Van, Diyarbakır, Trabzon, Sivas, Konya, Edirne and Sakarya, it also represents Sarajevo, Kmotini, Skopje and Pristina. Our children [yavru] 
who will visit the museum will say, 'wow, who was I [how glorious I once was]!' We do not want our youth to be raised with an inferiority complex. (Istanbul Metropolitan Municipality Website, 2009) ${ }^{4}$

P1453 is phenomenally popular and receives, according to official records, a high volume of visitors for its small physical size: up to 6,900 a day sometimes, and over half a million per year. During my own numerous visits, the museum was frequently packed, with large crowds often predominantly populated by conservative Muslim visitors (conspicuous because of Islamic dress) who engage closely, not just by reading and looking but also through other behaviours. These include bodily gestures, exclamations, expressions of emotion and being moved, including crying, and taking selfies against the backdrop of the panorama.

The museum is not spectacular from outside: it is a small, domed building with reproductions of nineteenth-century, Western orientalist engravings on its exterior walls, such as those common in magazines like the Illustrated London News. As we move into the museum, we are greeted by a mannequin of Sultan Mehmet II, often called 'Fatih', or 'the Conquerer', ${ }^{5}$ and we then negotiate a complicated route through a number of corridors. On the walls of these are reproductions of images of Constantinople and of Sultan Mehmet II, accompanied by text panels containing around 15,000 words of historical narrative of and explanation for the Conquest, and characterizations of Sultan Mehmet II. As an example, one of the English-language summaries of the Turkish texts gives an account of the predestination of the Conquest:

This painting [actually an enlargement of a passage of calligraphic Islamic script] illustrates the Conquest Hadith of the Prophet Muhammad. The most well-known evangel regarding the Conquest of the city is the 'Conquest Event'. 'The city of Konstantinniye is destined to be conquered. The Commander that will conquer that city is a good one. And the army that will conquest [sic] the city is a good one.' This Hadith encourages the conqueror and his army even more, thus his army conquered the city with a great will and determinism [sic].

This is one of several references to the importance of the hadith and to Islam, framing other texts about the necessity for conquest, since Constantinople was in decline and 'waiting' for a new era, the technological ingenuity of the Ottoman forces, the innovative use of artillery cannon, and Sultan Mehmet II's character: Mehmet II was 'clever, stubborn, sharp, active and liked physical sports', understood literature and science, and 'grew up dreaming of the Conquest'. One text states that his 'sword was never sheathed; his boots never left his feet'. Another key theme is the 'tolerance' and the 'justice' of the Ottomans towards the defeated Byzantines: 
By way of their gaza politics [a name given to a holy war waged in order to protect or spread Islam], justice, tolerance and social, cultural and religious practices, the Ottomans firstly conquered people's hearts and then their castles.

The interpretive framing of the Conquest presents it explicitly as divinely ordained, rightful, and progressive. Nevertheless, the texts show an obvious political inflection in which a singular view of the Conquest emerges. As might be imagined, there are competing stories of the Conquest, including many from primary sources (Mansel, 1995: 1; Feldman, 2008), and these are much less glorious in nature. Some recount, for example, gratuitous slaughter after the fall of the city, and the pressing into sexual slavery of the city's youths. No space is accorded to contradictory narratives such as these. The idea of 'conquest' is unambiguously positive where in other settings it might be a term that bespeaks violent invasion and appropriation, thus providing material to build a 'politics of regret' into Turkish national identity frameworks. Any such qualms are dispelled because of the idea of predestination, the selective remembering of events, righteousness, and the focus on the victorious Sultan Mehmet II's magnanimity and fairness, when he issued a firman allowing for the continued practice of diverse religions among his new subjects. Indeed, in the museum there is a film of the firman being read in public, to the joyful and relieved responses of the assembled citizens.

After this textual set-up, we proceed to the panorama room itself. The panorama shows the battle in progress. We emerge from a staircase as if into the past, finding ourselves in a domed room, with a monumental 360-degree painting of the battle, 3D replica weapons strewn around, and an audiotrack of battle sounds and traditional mehter military music. There are reputedly over 10,000 figures in the painting, and all of them men at war, characterizing the masculinized nature of the national story on display. On occasion, the warding personnel wear Ottoman costume. When we look at the scenes in the painting, we first face an image of a tree, a further reference to Osman's vision. To the right is Sultan Mehmet II on horseback, directing the battle (Image 4.1). In the sky projectiles fly overhead, and the sun breaks cloud cover - perhaps a play on the long-standing Western pictorial tradition of signalling victory and a new, better era through depicting meteorological changes. There is some magic here too: an image of Sultan Mehmet's face is discernible in the cloud formations. Elsewhere we see corps of soldiers rushing into battle; 'sappers' digging tunnels under the walls of Constantinople for explosives; defensive 'Greek fire' (large ceramic pots of flaming oil and rags) falling down from above as if on the visitors themselves (Image 4.2); and the walls being breached in various places. In one of these scenes, the soldier Ulubatlı Hasan (Hasan of Ulubat) hoists the Ottoman flag on the walls (Image 4.3). There is a well-known story that he defended the flag heroically, inspiring the Ottomans and disheartening the defenders 


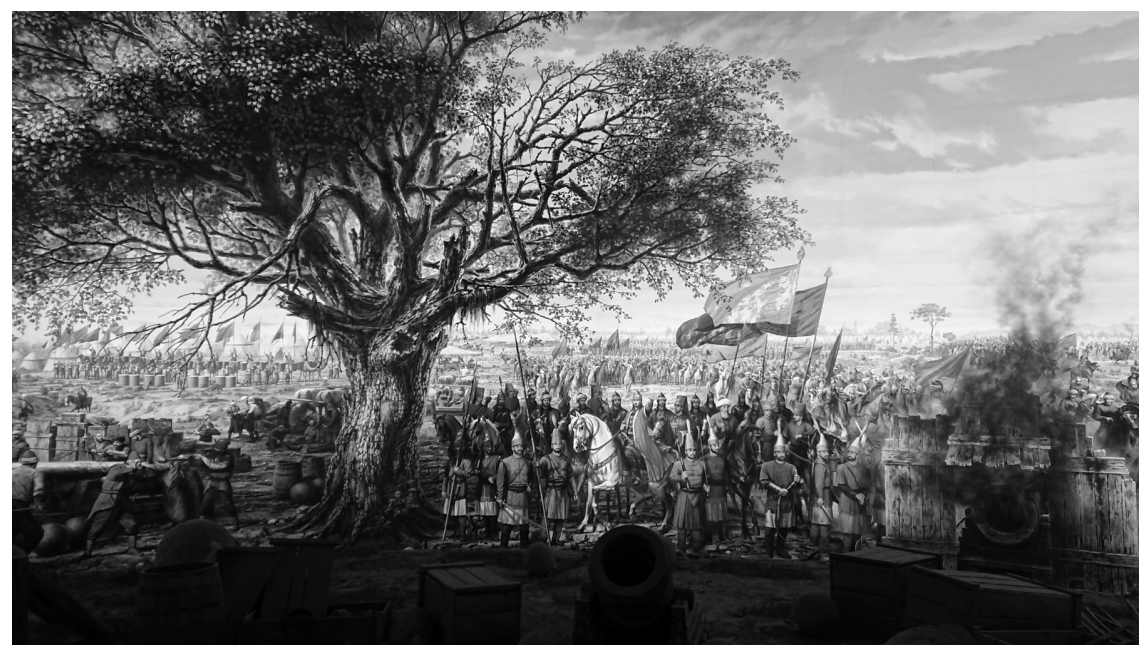

Image 4.I Sultan Mehmet II on his white horse in the middle of his retinue. Panorama 1453 Museum.

Source: Photo by Gönül Bozoğlu. Art Director of the Museum is Hașim Vatandaș. Artists are Haşim Vatandaş, Ramazan Erkut, Yaşar Zeynalov, Oksana Legka, Ahmet Kaya (storyboard), Hasan H. Dinçer, Atilla Tunca, and Murat Efe.

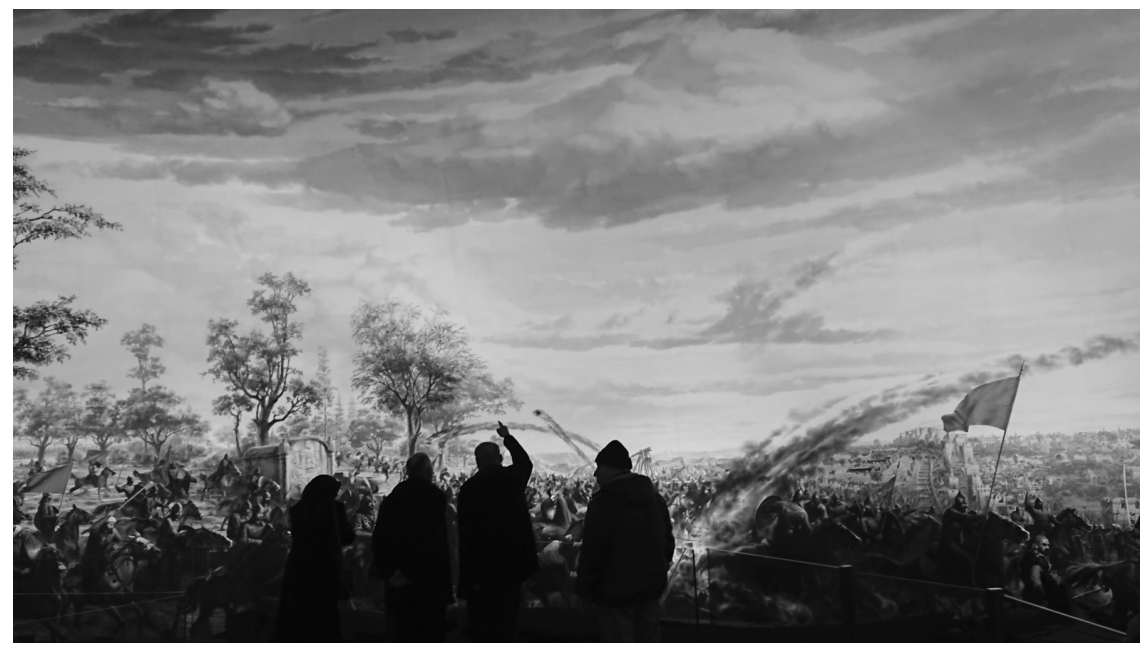

Image 4.2 A group of visitors look at the Greek fire flying towards the Ottoman soldiers. Source: Photo by Gönül Bozoğlu. Art Director of the Museum is Hașim Vatandaș. Artists are Haşim Vatandaş, Ramazan Erkut, Yaşar Zeynalov, Oksana Legka, Ahmet Kaya (storyboard), Hasan H. Dinçer, Atilla Tunca, and Murat Efe. 


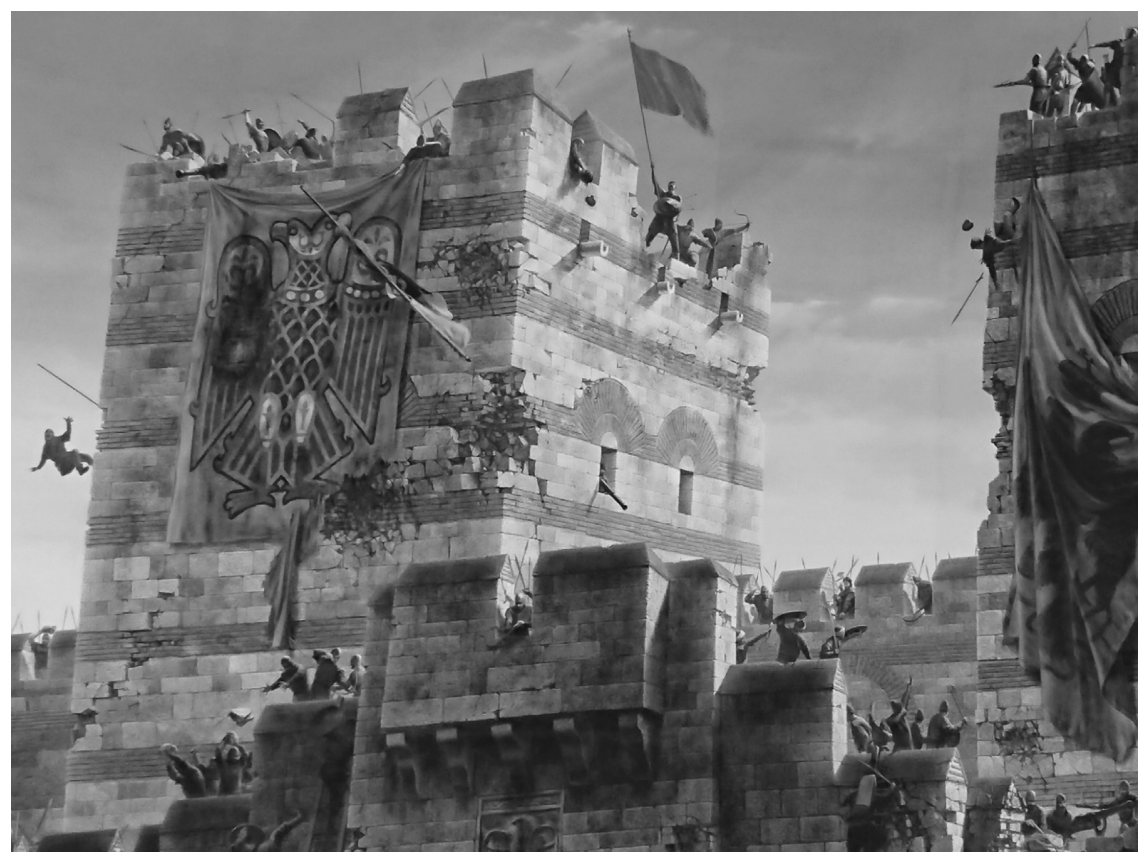

Image 4.3 The breaching of one of the bastions: Ulubatlı Hasan (Hasan of Ulubat) is first to hoist the Ottoman flag on the wall.

Source: Photo by Gönül Bozoğlu. Art Director of the Museum is Hașim Vatandaș. Artists are Haşim Vatandaș, Ramazan Erkut, Yașar Zeynalov, Oksana Legka, Ahmet Kaya (storyboard), Hasan H. Dinçer, Atilla Tunca, and Murat Efe.

notwithstanding the multiple arrow injuries from which he subsequently died. Hasan is widely celebrated in ubiquitous imagery and public statuary in Turkey an Istanbul metro station is named after him near the site of his supposed feat of heroism - but his real existence has been doubted (Hür, 2014). He is nevertheless an influential symbol of Ottoman valour and self-sacrifice.

Indeed, the different scenes in the panorama are far from obscure in their references: they were noticed by various respondents during my visitor studies, and this is unsurprising given their prominence in popular culture, for example in the 2012 film Fetih 1453 about the Conquest, in which characters such as Hasan of Ulubat appear. In 2015 I conducted 103 ten- to thirty-minute interviews with visitors to understand the importance for them of the museum visit. ${ }^{6}$ There is no space here for a full account of the responses (see Bozoğlu 2020 for this); instead, I concentrate on exemplary themes and statements from visitors. These included some of the tropes discussed above, as, for example, 
when visitors frequently referred to the Ottomans as their ancestors (ecdat), often expressing shame that they could not live up to their memory:

We were curious about what the Ottomans did for us. Although this is my fifth visit, I am still astounded by what they did. We do not even pray for them! Not in a mosque or in everyday life! I will continue to come back here again and again.

(Female, 28, housewife)

Some expressed a desire to return to or reprise an Ottoman existence. For example, visitors promised themselves to cultivate more 'Ottoman' behaviour in future (in one case, a 'more Ottoman soul'). Some used the panorama to imagine themselves into the battle, feeding into desires to revert to old ways of life that were also expressions of loss of identity and refusal of modernity:

Experiencing that moment [the Conquest] is so different. I wish I was on one of those horses. Why did that not happen? I really want that, I mean it: to be one of those who were holding a shield. At least to teach swords and shields to people is our duty.

(Male, 29, butcher)

Alongside pride and admiration of the Ottoman achievement (e.g. "We have intimidated the world!'), another conspicuous theme was the importance of regaining memory that had been forgotten or, more often, 'taken away' by others. In some statements, these 'others' were not explicitly named ('They took our ancestors away from us'), but could clearly be identified with the secular, Kemalist elite, as was made explicit by others:

The Republican period erased our society's memory. Where is $m y$ [ruler]? They sent him into exile!

(Male, 60, retired civil servant)

And one twenty-one-year-old male commented:

In fact, the new generation and we included have been forced to focus on the Republic's [history and ideology] and they have been trying to make us forget about our origin and real past. This museum was established to stop this. In a similar way, making films and TV serials has the same reason: to prevent us from forgetting our self [' $\ddot{o} z ’]$.

(Male, 21, student)

Turkish National TV channels show serials about the Ottomans such as Dirilis (Resurrection). There are also film productions such as Fetih 1453 (Conquest 1453), and at the time of writing more such shows are being produced, 
notably Payitaht: Abdülhamid. Many respondents mentioned these. This crossreferencing between televisual and museal representations of the Ottomans is indicative of the intertextuality of different representations and their integrated meaning for people for whom the Ottomans have become salient for identity. This intertextuality is actively supported by the JDP: alongside endorsements of P1453, Erdoğan has also encouraged people to watch historical dramas about the Ottomans, such as Dirilis and, subsequent to my data collection, Payitaht: Abdülhamid, so that '[we may] understand our history' and 'know what we once were' (Armstrong 2018).

The project of regaining a past, and an identity connected to it, also carried through into a number of statements directly or indirectly connecting the Ottomans to Erdoğan or suggesting that it was the JDP who were responsible for bringing back the 'forgotten' and 'real' past:

I have come to see what the Ottomans did for us. The people [i.e. politicians] who are fighting for a seat should come and see this place. Also, the ones who begrudge Erdoğan his position should come and see this. I feel very emotional. This is my first visit but I will come back here. You see how Turkey was rescued with such difficulty, how we have come to this situation with such difficulty. With such difficulty, our integrity ['namus'] and honour were rescued and now we are here. People should pray and give thanks. Like the Ottomans, our dear president [Erdoğan] is also fighting for these values. People should know the value of our president.

(Female, 65, housewife)

Responses of this kind, and those that involve implicit or explicit expressions of grievance towards secular Republicans, support the argument that the appeal of the JDP's neo-Ottomanist nostalgia is to 'mend' people's relationship with the past, and to reinstate what Atatürk disestablished in 1923 (Temelkuran, 2015: 11). What should be evident from this is that responses of this kind were about something that was not evidently present in the museum: there was no explicit mention in displays of Atatürk or of the early Republic, and yet this was a key reference point and object of resentment for many of my respondents. 'Resentment' (and 'ressentiment') has nuanced and varied definitions across literatures (Demertzis, 2006), but in the setting of P1453 I mean, with resentment, the sense that emerged from respondents of having been unjustly deprived - by a dominant political elite with unshared values - of one's historical memory and identity. What was 'taken' from visitors by this enemy group, in other words, was that faculty to identify oneself in history as Ottoman. This faculty pertains to complex contemporary political and social contests, including a clash between secularism and state-sponsored Sunni Islam.

This begs the questions: To whom did the panorama's producers think the museum would appeal and why? What effect did its producers hope for in those audiences? There is insufficient space here to discuss the interviews I undertook 
with its producers (for more discussion, see Bozoğlu, 2020), but three main themes emerged from this. Firstly, the producers insisted on their historical neutrality and objectivity, in what was both a disciplinary ideal of achieving accuracy and a means of warding off the accusations of partisanship and selective remembering that had appeared in unsympathetic news media outlets (Aytalar and Oktay, 2009). Secondly, the producers were content to see the emotional and indeed the religious response that the museum provoked in its visitors:

Well, people get very emotional and say they have goose bumps, because there are a lot of reasons, and we worked hard on it, and there are so many details, and that gets an appreciative response. We were neutral here and we just showed how Istanbul was conquered. . . . There are queues on the weekend, and we hear people cry, and we hear people pray, so we are happy with what we achieved.

(Interview with a producer, 2015)

Thirdly, the insistence on historical 'truth' meant that the producers disavowed any attempt to target specific visitors, even if in fact the audience profile is limited. For them, the panorama was not a matter of tailoring the past to suit a particular group; it was simply truth-telling. Of course, neutrality in curatorship is a long-standing fallacy in museology, and the denial of governmentality it involves may be a question of institutional face and/or naturalization processes at work. Actors of governmentality do not all covertly subscribe to a surreptitious project of forging citizenship that they hide from audiences and interviewers. In her work on Northern Cyprus as a 'make-believe' state, Yael Navaro-Yashin (2012) discusses banal, pervasive, and coincidental affects of administrations and modes of governance that are generative. They can 'produce' a state, but potentially also its history. In a governmental view, such affects may frame the 'objective' worldviews and desires of producers as selfregulating subjects themselves, contributing to the slow repetition of stories and expert claims made in public memory culture and authorized heritage discourse (Smith, 2006). If it seems easy to debunk the apolitical neutrality of the curatorial position described in the quotation, it certainly seems not to match the political and antagonistic content of the visitor comments, the pride taken by producers in visitors' heightened emotional and religious responses, or the complex political history of the museum and its overt party links. To read against the grain of the quotation, which I have taken care to say does need not be considered disingenuous, a more nuanced understanding of the museum's situated meaning for politics and society is needed. I turn to this now.

\section{Discussion: emotional politics of the past}

To understand why visitors expressed resentment against an absent enemy, we must consider the museum in its time. It opened in 2009, although it had been 
in germination and development for some years previously. By the time of the opening, the JDP had been in power for nearly seven years, and the museum can be seen as part of a general project of instituting a neo-Ottoman memory culture to accompany, or in another view to supplant, the memory cultures of Atatürk and the early Republic that have such pronounced public visibility in Turkey (Navaro-Yashin, 2013; Tharoor, 2017). These can be and have been seen as antagonistic memory cultures with separate heroes, symbols, narratives, and meanings that crystallize in different political and civil ideals of the nation: as secular, modernist, and Westernized; or as (Sunni) Islamic, fundamentally non- or anti-Western and atavistic (Zencirci, 2014: 3). These antagonistic ideals attach to antagonistic groups, each of which celebrates one past but not the other, avails itself of an associated, specific repertoire of emotional practice, and takes a specific political side. It is in the interplays between historical memory, emotion, and political standpoint, among other dimensions, that group identities are made and maintained. The JDP and its supporters were, upon the opening of the museum, in a position of consolidated strength. Indeed, the JDP was later to increase its percentage of the vote in the 2011 general elections, marking its third victory at the ballot (of four, at the time of writing). The secular legacy of Atatürk and its supporters were beleaguered.

This brings up a question: Why, at a time when the JDP and its supporters enjoyed dominant status, was there a need for the museum? One possible answer is that in Turkey there is always a sense of the latent possibility of dramatic political change, for example through coup attempts or as threatened in cases of mass civil disorder such in the 2013 Gezi Protests (Whitehead and Bozoğlu, 2016), that make any regime fragile, however dominant it may seem. Notwithstanding its typically large margin of support at the ballot box, the JDP needs to actively cultivate its supporters and provide identity resources for them. As a consequence, we may see P1453 as such a provision, offering objects of attachment (the Ottomans) and implicit objects for resentment (secularists/Kemalists). Atatürk and his political followers are, in this sense, an absent presence (Law, 2002) at the museum: they are not there in the displays, images, and texts, but their absence is built into the historiographical structure of the representation; the museum has been, as it were, designed against their memory. Beyond the museum, Ottoman historical memory and identity is more generally discursively pitted against the JDP's secularist enemies, as when Erdogan, at a 2014 rally, exhorted his followers to give the Republican People's Party (Cumhuriyet Halk Partisi) an 'Ottoman Slap' at the ballot boxes (Reuters and Haaretz, 2014). By authorizing the story of the Conquest and celebrating the Ottomans and through its intertextual arrangement in public discursive space, the museum opened up an alternative nationalist historiography to contrast with the previously dominant Republican national story. At the same time, the glorification of Sultan Mehmet II can be seen as an attempt to supplant Atatürk's post-mortem cult of personality, as if to create a new national hero for attachment. In these senses it is unsurprising that visitors identified 
modern secularists as their enemy, rather than the Byzantines. The Byzantines were definitely, definitively defeated; the secularists, only temporarily (the fragility of the JDP ascendancy has indeed been verified at the time of writing, in the June 2019 municipal election won by Ekrem İmamoğlu, leading a coalition of the secularist Republican People's Party and the Good Party (Íyi Parti), both of which represent secularist and Kemalist interests).

So far, I have shown the close interrelation between historical memory politics and party politics in the governmental framing of the museum. P1453 presents an emotionalized, selective, and dramatic narrative of the past into which visitors have the opportunity to imagine themselves and thus to configure identities - for themselves and for their enemies. It could be argued that P1453 shares many of the techniques of populist discourse: the great and special man (Sultan Mehmet II), magically predestined to greatness; the friend-and-foe dynamics (Mudde, 2004; Kaya, 2016); the heroic struggle and righteousness of the ordinary people, including emblematic heroes like Hasan who trigger learned emotional responses; and so on. To this we might add the popular appeal of the representational technology of the panorama, with its high drama and direct messages. It is not a long stretch to suggest that Mehmet II might function as a proxy figure for Erdoğan. As far back as his Istanbul mayoral campaign prior to election in 1994, he had played on the theme of the 'second conquest' of the city, which he promised to carry 'from darkness to light', 'just as Sultan Mehmed of the Ottoman Empire had done when he had conquered the city in 1453' (in Büyüksaraç, 2004). There is then a strategic interdependence of heritage discourse and party politics.

I have also presented a sample of visitor comments that represent those visitors' enthusiastic take-up of the opportunities presented by the museum. These are opportunities for visitors to relay imaginatively between past and present (once again, keeping the 'bliss of the Conquest alive'). Smith and Campbell point out that people desire to have emotional responses, and they seek them out and look to museums and heritage sites to mediate them; they become skilled at recognizing and 'working with' their emotions in such settings (2015: 445). Although it would be misleading to suggest that this is universally true of all museum visitors, at P1453 the obvious emotional behaviour of visitors chimes with Smith and Campbell's view. The immersive, time-travel technology of the panorama is important here. You need to be able to travel back in time to fully experience what you have lost, and therefore to be able to savour that loss. Consequently, the museum acts as a space in which to express emotional grievance against a social and political enemy group responsible for depriving visitors of their notional past and identity. In my sample, this enemy group represented a loose construct of repressive secularism against which respondents felt it was finally possible to rail, after decades of privation.

However, such emotional expressions did not involve an evident release, so much as a mixture of continued animosity and vigilance. Rico et al. (2017) suggest that it is anger, and not fear, that is the defining emotion of populism, 
which, as a 'Manichean ideology that conceives politics as the antagonistic struggle between the benevolent people and the evil elite' (drawing on Mudde, 2004), should be 'more appealing to angry than to anxious citizens', and more likely to mobilize subjects who, in a fearful state, would be passive. Certainly, my visitor studies showed expressions of anger. But I have tried to suggest that this is also a result of latent anxiety about political futures: that the foes who repressed people's senses of their 'history' and identity may return to power. A way through this is to suggest that it is more helpful to see the emotions of fear and anger as consecutive rather than singular, and that, as Margaret Wetherell suggests, emotions may run in 'affective-discursive loops', triggering and flowing into one another recursively (Wetherell, 2012). This also accounts for flows and relays between other emotions in P1453, including shame at not living up to the example of one's notional ancestors.

What is needed, in cases like P1453, is a relational study of memory, politics, and emotion capable of capturing the meanings, uses, and salience of the past in the present in public institutions, space, and discourse and in people's lives. The study of emotion in politics has a relatively developed tradition, especially relating to the surge of interest in populism (see Clarke et al., 2006; Wright-Neville and Smith, 2009; Eklundh and Massey, 2013; Kassab, 2016; Rico et al., 2017). In this literature, broadly speaking, there have been moves to overcome rationalist models that see emotion as extraneous to or undesirable within politics, towards understandings of politics and emotion as always entangled (Clarke et al., 2006: 7-8). Meanwhile, in memory and heritage studies there is an ongoing turn to affect (Smith, 2006; Macdonald, 2013; Smith and Campbell, 2015; Witcomb, 2015, 2016; Tolia-Kelly et al., 2017). Here too, there has been a move away from reductively cognitive understandings of people's understandings of the past, towards more integrated models of meaning-making that include embodied, sensory, and affective dimensions. In this view, the past can be emotional matter, and we can ask socio-political questions about why this is, for whom, when, and where.

In both literatures, there is the possibility of focusing on the emotional work of the powerful actors - party politicians, or museums, for example - which may aim to elicit, prompt, and mobilize emotions among citizens. Otherwise, one can focus on the emotional responses of the citizens who are the targets of this work. A third way is to see this relationship dynamically. Certain emotional memory cultures - such as those tied to the commemoration of specific events like the Conquest of Constantinople, or historical individuals like Sultan Mehmet II - have a pre-existence and salience among some social groups, and members of those groups go both to sites of 'heritage' and memory, be they museums or historical re-enactments in public space, and to the ballot box. In some cases, such memory cultures are, because of the familiarity of their narratives and emotional patternings, amenable to cultivation, exploitation, reworking, and investment that are simultaneously in the interests of powerful political actors, while also responding to the emotional needs of citizens 
to conceptualize and position themselves in history and society. This is better seen as an interplay between top-down and from-below emotional memory practice $-\mathrm{a}$ tacit negotiation between the needs of political actors and those of citizens - rather than a unidirectional emotional manipulation of the masses by way of imposed historical memory. The museum is at once a strategic mobilization of emotions and a site for the willing to practise emotion and to exercise a politico-historical identity based on animosity.

In the still-somewhat-separate literatures on affect and emotion generally, politics and emotion, and heritage and emotion, we find discrete conceptions of community. Emotional communities share emotional repertoires (see Wetherell, 2012). Political communities share political beliefs, interests, and standpoints (Walzer, 1983). And memory communities share attachment to given pasts (Irwin-Zarecka, 2007). I suggest that these are not so much comparable as overlapping structures. So, for example, groups who share political beliefs often also share attachments to certain pasts, and emotional repertoires that make these politics and attachments meaningful and personal. Nor, obviously, are these dimensions of community the only ones that we can speak of religiosity, for example, is another. The overlap between such dimensions of community may not always be total. It is unlikely that everyone for whom the Ottomans are important identity references will also be ardent JDP supporters. But my suggestion is that there are cases, such as the one represented by my P1453 study, where there is a high degree of consonance between the political, emotional, and memory dimensions of community, or, to put it differently, where these dimensions interlock closely and tightly.

\section{Final thoughts: historical memory and social division}

The next steps for understanding the emotional politics of the past are to understand this multidimensional nature of community and, then, what this means for broader social relations between communities who have to negotiate what Ash Amin calls the 'politics of propinquity' (2002), which 'derives from the fact that groups marked, perceived and/or identifying as different from one another live in the same "places"" (Whitehead and Lanz, 2020). Different negotiations of propinquity can involve significant intergroup tension, as I saw in my research, which showed up again the well-remarked antagonism between conservative Sunni Muslim groups and secular Kemalists (Zencirci, 2014: 3). Such tension may be tantamount to social division and polarization.

In Ian Lustick's classic definition, a deeply divided society is where 'ascriptive ties generate an antagonistic segmentation of society, based on terminal identities with high political salience, sustained over a substantial period and a wide variety of issues'. This characterizes well the situation where family, social networks, and ways of life can lead to relatively static identities and attachments both to political and memory cultures in Turkey. Lustick adds that, as a minimum condition, 'boundaries between rival groups must be sharp enough so that membership is clear and, with few exceptions, unchangeable' (Lustick, 
1979: 325; see Guelke, 2012, for alternative definitions), and this too is recognizable in clear distinctions of the physical habitus - particularly between secularists and many conservative Muslims - and the relative difficulty of, and lack of inclination for, 'breaking out' of one's social milieu or changing one's dispositions. The museum also functions as a performative site of membership, for the self-selection of the audience and their evident physical and emotional engagements with the museum displays are also behaviours that construct collectivity and the sense that there are like-minded people here. There is no space in this chapter to explore this important aspect, but we should remember that visitors' behaviours and gaze are not entirely oriented towards their solitary encounters with the displays, but also towards one another.

Lustick's 'deeply divided society' can also be understood in relation to polarization - a common but imprecise catchword in Turkey - which, in Jack Barbalet's discussion, is when different social groups 'fail to share common reference points cognitively and affectively, that is to say they literally live in different worlds'. This means that there is a fundamental breakdown in sympathy, so that the 'humanity of the other is simply not accessible' (Barbalet, 2006: 46-47). The result is a deep divide and animosity that cannot be bridged unless there is a significant change of circumstances, such as, perhaps, the entrance onto the scene of a new common foe that unites previously antagonistic parties. The antagonistic play of different repertoires of historical narratives, symbols, and heroes can be seen as part of this divide, as 'reference points' specific to one group that are not shared by another, meaning that people 'live in different worlds', or rather, different imaginations of Turkey, and fail to sympathize with others to the point of resentment.

What P1453 helps to show is the way in which political and emotional attachments to a particular past can build and consolidate social division. In Lustick's 'control' model of divided society, as opposed to a consociational model based on forms of collaboration and compromise, a divided society requires mechanisms to impose stability. Such mechanisms may include legal ones or the persecution of dissidents as enemies of the state, but they may also include official heritage management and uses of the past. We might, in this sense, see P1453 as a physical and symbolic site for the cultivation of animosity that is in some sense a mechanism of control. This mechanism may help to guarantee the stability and ascendancy of one political community, that is also a memory and emotional community, at the expense of another - not only to keep the 'sensation of the conquest alive', but also to keep alive resentful affects and the corollary inclination to act against foes, if not 'with swords and shields', then with the vote.

The critical point is that emotionalized historical memory cultures are imbricated with the 'politics of propinquity', and that imbrication is both foundational and dynamic. We can talk of strategically opportune constructions of memory to achieve political ends, as when the JDP 'invents tradition' (Hobsbawm and Ranger, [1983]1992) or develops new historical mythologies. But it is important to recognize that these are often affective transformations of durable structures 
of public memory, including latent or sometimes suppressed ones, which is why they have power and salience for communities; it is why ideological approaches are invisible to some producers or naturalized as objective, neutral history - 'telling it as it happened'. It is also why there is a need to find ways to understand and show the mutuality of political, emotional, and memory cultures. P1453 offers an immersive return to the past, an occasion for imaginative work through which people simultaneously regain an imagined past while also facing up to its loss and vilifying contemporary social and political foes. Here, the significance of the Conquest is that it has to be 'alive' and yet 'taken away from us' simultaneously, in order for people to feel both loss and the blissful possibility of rebecoming, to feel both grievance and the promise of vengeance, and to be both victim and victor.

\section{Acknowledgement}

The research for this chapter was undertaken as part of the CoHERE project, which received funding from the European Union's Horizon 2020 research and innovation programme under Grant Agreement No. 693289.

\section{Notes}

1 Topbaş, Özleyis (2009). Comment from museum guestbook reproduced in 'Significant Visitors' section of the Panorama 1453 Museum website. Notably, subsequent to the resignation of Kadir Topbas as Mayor of Istanbul, comments by him and his wife about the museum were removed from the website, alongside others. The new 'Significant Visitors' page on the museum website only has one comment, made by the president, Recep Tayyip Erdoğan: https://www.panoramikmuze.com/en/significant-visits (accessed 14 May 2019).

2 Another, related, dimension is the use of the Ottoman Empire as inspiration for regaining a position of international geopolitical power, as discussed by Kaya and Tecmen in this volume.

3 'About'section, Turkish Panorama 1453 Museum Website (2018), http://panoramikmuze. com/panorama-1453/hakk\%C4\%B1nda.aspx\# (accessed 15 May 2018), my translation. These texts reflect the content of the website until 2018, during which changes were made and texts removed.

4 'Türkiye'nin ilk panoramik müzesi "İstanbul'un Fethi'ni” yeniden yaşatacak . . .' http:// www.ibb.gov.tr/tr-TR/Lists/Haber/DispForm.aspx?ID=17004 (accessed on 14 July 2019).

5 This was put in place in 2016.

6 This was a random sample (approaching every third visitor or visitor group) over weekdays and weekends. The resulting data was coded using NVivo. It should be noted that this is not a statistically representative sample of the whole population of visitors, but rather a view into the dispositions and responses of a limited number of people. Alongside the short interviews, I employed a number of other qualitative visitor studies that are not presented here.

\section{References}

Amin, A. 2002. "Ethnicity and the Multicultural City: Living with Diversity." Environment and Planning 34 (6): 959-980. 
Armstrong, W. 2018. "Ottoman Sultan Abdülhamid II, Yesterday and Today." Hürriyet Daily News. Accessed 15 May 2018. www.hurriyetdailynews.com/opinion/william-armstrong/ ottoman-sultan-abdulhamid-ii-yesterday-and-today-125909

Aytalar, A. and Oktay, E. T. 2009. "Açılışı iki defa yapılan müze ideoloji kurbanı mı." Hürriyet, 10 March. Accessed 5 November 2018. www.hurriyet.com.tr/gundem/acilisiiki-defa-yapilan-muze-ideoloji-kurbani-mi-11172759

Barbalet, J. 2006. "Emotions in Politics: From the Ballot to Suicide Terrorism.” In Emotion, Politics and Society. Edited by Simon Clarke, Paul Hoggett and Simon Thompson, 31-55. Hampshire: Palgrave Macmillan.

Bozoğlu, G. 2020. Museums, Memory and Emotion: The Affective Politics of the Past in Turkey. London: Routledge, in press.

Büyüksaraç, G. B. 2004. "Conquering Istanbul: The Controversy over the Taksim Mosque Project." Anthropology in Action: Journal of Applied Anthropology 11: 22-31.

Çınar, A. 2001. "National History as a Contested Site: The Conquest of Istanbul and Islamist Negotiations of the Nation." Comparative Studies in Society and History 43 (2): 364-391.

Clarke, S., Hoggett, P. and Thompson, S. (eds.) 2006. Emotion, Politics and Society. Hampshire: Palgrave Macmillan.

Cubitt, G. 2007. History and Memory. Manchester: Manchester University Press.

Demertzis, N. 2006. "Emotions and Populism." In Emotion, Politics and Society. Edited by Simon Clarke, Paul Hoggett and Simon Thompson, 103-122. Hampshire: Palgrave Macmillan.

Eklundh, E. and Massey, R. 2013. "Unfolding the Political: Voices of Aesthetics and Emotions." Political Perspectives 7 (2): 1-10. www.politicalperspectives.org.uk/wp-content/ uploads/Unfolding-introduction.pdf

Feldman, R. T. 2008. The Fall of Constantinople. Minneapolis: Twenty-First Century Books.

Girard, M. 2015. "What Heritage Tells Us about the Turkish State and Turkish Society." European Journal of Turkish Studies. https://ejts.revues.org/5227

Göle, N. 1997. "Secularism and Islamism in Turkey: The Making of Elites and CounterElites." The Middle East Journal 51 (1): 46-58. www.jstor.org/stable/4329022

Guelke, A. 2012. Politics in Deeply Divided Societies. London: Polity Books.

Hobsbawm, E. and Ranger, T. R. (1983) 1992. The Invention of Tradition. Cambridge: Cambridge University Press.

Hür, A. 2014. "561 yıldır fethetmeye doyamadığımız İstanbul.” Radikal, June 1. Accessed 5 November 2018. www.radikal.com.tr/yazarlar/ayse-hur/561-yildir-fethetmeye-doya madigimiz-istanbul-1194910/

Hürriyet Daily News. 2016. "Istanbul Marks 1453 Ottoman Conquest of Istanbul with Grandiose Ceremony." May 29. Accessed 5 November 2018. www.hurriyetdailynews.com/ istanbul-marks-1453-ottoman-conquest-of-istanbul-with-grandiose-ceremony.aspx?Pag $\mathrm{eID}=238 \& \mathrm{NID}=99825 \& \mathrm{News}$ CatID $=341$

Irwin-Zarecka, I. 2007. Frames of Remembrance: The Dynamics of Collective Memory. London: Routledge.

Istanbul Metropolitan Municipality Website. 2009. “Türkiye'nin ilk panoramik müzesi “İstanbul'un Fethi'ni” yeniden yaşatacak . . .’January 31. Accessed 14 July 2019. http:// www.ibb.gov.tr/tr-TR/Lists/Haber/DispForm.aspx?ID=17004

Kassab, H. S. 2016. The Power of Emotion in Politics, Philosophy, and Ideology. London: Palgrave Macmillan.

Kaya, A. 2016. "The Rise of Populist Extremism in Europe: Theoretical Tools for Comparison." Cohere Critical Archive. http://cohere-ca.ncl.ac.uk/\#/grid/125 
Law, J. 2002. "On Hidden Heterogeneities: Complexity, Formalism, and Aircraft Design." In Complexities: Social Studies of Knowledge Practices. Edited by John Law and Annemarie Mol, 116-141. Durham, NC: Duke University Press.

Lustick, I. 1979. "Stability in Deeply Divided Societies: Consociationalism versus Control." World Politics 31 (3): 325-344.

Macdonald, S. 2013. Memorylands: Heritage and Identity in Europe Today. London: Routledge. Mansel, P. 1995. Constantinople: City of the World's Desire, 1453-1924. London: John Murray. Mudde, C. 2004. "The Populist Zeitgeist." Government and Opposition 39 (4): 541-563.

Navaro-Yashin, Y. 2002. Faces of the State: Secularism and Public Life in Turkey. Princeton: Princeton University Press.

Navaro-Yashin, Y. 2012. The Make-Believe Space: Affective Geography in a Postwar Polity. Durham, NC: Duke University Press.

Navaro-Yashin, Y. 2013. "Editorial-Breaking Memory, Spoiling Memorization: The Taksim Protests in Istanbul in Cultural Anthropology (Hot Spot): An Impromptu Uprising: Ethnographic Reflections on the Gezi Park Protests in Turkey." Electronic document. https://culanth.org/ fieldsights/411-editorial-breaking-memory-spoiling-memorization-the-taksim-protestsin-istanbul

Reuters and Haaretz. 2014. "Turkey's Erdogan Urges Voters to 'Ottoman Slap' Rivals." March 29. Accessed 5 November 2018. www.haaretz.com/middle-east-news/.premium1.582711

Rico, G., Guinjoan, M. and Anduiza, E. 2017. "The Emotional Underpinnings of Populism: How Anger and Fear Affect Populist Attitudes." Swiss Political Science Review 23 (4): 444-461. doi: 10.1111/spsr.12261

Smith, L. 2006. The Uses of Heritage. London: Routledge.

Smith, L. and Campbell, G. 2015. "The Elephant in the Room: Heritage, Affect and Emotion." In A Companion to Heritage Studies. Edited by William Logan, Mairead Nic Craith and Ullrich Kockel, 443-460. Chichester: Wiley-Blackwell.

Temelkuran, E. 2015. Turkey: The Insane and the Melancholy. London: Zed Books.

Tharoor, I. 2017. "Why Turkey's President Cares So Much about an 11th-Century Battle." The Washington Post, 1 September. Accessed 5 November 2018. www.washingtonpost. com/news/worldviews/wp/2017/09/01/why-turkeys-president-cares-so-much-aboutan-11th-century-battle/?utm_term $=.3 \mathrm{a} 7 \mathrm{~d} 497 \mathrm{f} 5 \mathrm{bdb}$

Tolia-Kelly, D. P., Waterton, E. and Watson, S. (eds.) 2017. Heritage, Affect and Emotion: Politics, Practices and Infrastructures. New York: Routledge.

Walzer, M. 1983. Spheres of Justice: A Defense of Pluralism and Equality. New York: Basic Books.

Wetherell, M. 2012. Affect and Emotion: A New Social Science Understanding. Thousand Oaks, CA: Sage Publications.

Witcomb, A. 2015. "Toward a Pedagogy of Feeling: Understanding How Museums Create a Space for Cross-Cultural Encounters." In The International Handbooks of Museum Studies: Museum Theory, Vol. 1. Edited by Andrea Witcomb and Kylie Message, 283-301. Oxford: John Wiley \& Sons, Ltd. https://doi.org/10.1002/9781118829059.wbihms116

Witcomb, A. 2016. "Beyond Sentimentality and Glorification: Using a History of Emotions Todeal with the Horrors of War." In Memory, Place and Identity: Commemoration and Remembrance of War and Conflict. Edited by Danielle Drozdzewski, Sarah De Nardi and Emma Waterton, 205-220. London: Routledge.

White, J. 2014. Muslim Nationalism and the New Turks. Princeton: Princeton University Press. 
Whitehead, C. and Bozoğlu, G. 2016. "Protest, Bodies, and the Grounds of Memory: Taksim Square as 'Heritage Site' and the 2013 Gezi Protests." Heritage \& Society 9 (1): 111-136. https://doi.org/10.1080/2159032X.2017.1301084

Whitehead, C. and Lanz, F. 2020. "Museums and a Progressive Sense of Place." In Museums and Communities: Diversity, Dialogue and Collaboration in an Age of Migrations. Edited by Viv Golding and Jenny Walklate. Newcastle: Cambridge Scholars Press, in press.

Wright-Neville, D. and Smith, D. 2009. "Political Rage: Terrorism and the Politics of Emotion." Global Change, Peace \& Security 21 (1): 85-98. doi: 10.1080/14781150802659390

Zencirci, G. 2014. "Civil Society's History: New Constructions of Ottoman Heritage by the Justice and Development Party in Turkey." European Journal of Turkish Studies. https:// journals.openedition.org/ejts/5076

Zurcher, E. 2016. “Opening and Closing of Turkey's Past.” History Today 66 (10). www. historytoday.com/erik-zurcher/opening-and-closing-turkey's-past 